\title{
Potential protein antiglycation, antiproliferation, and in silico study on the antidiabetic enzymes of bioactive metabolites from Adonis microcarpa DC and their ADMET properties
}

\author{
Howaida Ibrahim Abd-Alla ${ }^{1 *}$, Amal Zaki Hassan ${ }^{1}$, Maha Mohamed Soltan², Ahmed Baker Abdelwahab ${ }^{3}$, Atef Gobran Hanna ${ }^{1}$ \\ ${ }^{1}$ Chemistry of Natural Compounds Department, Pharmaceutical and Drug Industries Research Division, National Research Centre, Dokki- Giza, Egypt. \\ ${ }^{2}$ Biology Unit, Central Laboratory for Pharmaceutical and Drug Industries Research Division, Chemistry of Medicinal Plants Department, National \\ Research Centre, Dokki-Giza, Egypt. \\ ${ }^{3}$ Plant Advanced Technologies (PAT), Vandoeuvre-les-Nancy, France.
}

\begin{tabular}{l}
\hline ARTICLE INFO \\
\hline Received on: 01/03/2021 \\
Accepted 0n: $28 / 05 / 2021$ \\
Available Online: $05 / 01 / 2022$ \\
\\
\hline Key words: \\
Adonis microcarpa DC, \\
chemical composition, \\
cytotoxicity, antiproliferative \\
effect, type 2 diabetes \\
inhibitors, antiglycation, \\
ADMET properties, \\
molecular docking.
\end{tabular}

\begin{abstract}
Adonis microcarpa DC has not been comprehensively studied for its phytochemical and biological properties. The

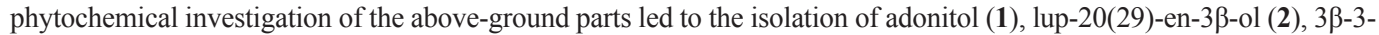
hydroxyolean-12-en-28-oate (3), strophanthidin-3-O- $\beta$-D-glucopyranosyl-( $1 \rightarrow 4)-\beta$-D-digitoxoside (4), strophanthidin3 -O- $\beta$-glucopyranosyl-( $(1 \rightarrow 4)-\beta$-boiviopyranoside $(5)$ and gluco-( $(1 \rightarrow 6)$-strophanthidin-3-O- $\beta$-glucopyranosyl- $(1 \rightarrow 4)$ $\beta$-boiviopyranoside (6). Their structures were assigned based on extensive 1D- and 2D-nuclear magnetic resonance spectral analyses. All the compounds are isolated for the first time from this species. Compounds $\mathbf{2}$ and $\mathbf{3}$ revealed high potency as antiglycated agents. The docking study introduced $\alpha$-amylase as a preferable candidate for inhibition compared to $\alpha$-glucosidase, with a slight superiority of $\mathbf{3}$. Aldose reductase was inhibited by $\mathbf{2}$ in a noncompetitive manner, while $\mathbf{3}$ probably was inactive toward it. Molecular docking suggested the activity of $\mathbf{2}$ and $\mathbf{3}$ as the possible inhibitors of $\alpha$-glucosidase and $\alpha$-amylase, while aldose reductase is an additional target of $\mathbf{2}$ by an allosteric effect. In silico physicochemical properties, such as absorption, distribution, metabolism, excretion, and toxicity parameters, of compounds were also predicted. Compounds 1, 2, and $\mathbf{3}$ were favorable in an acceptable prediction. The antiproliferative potentials on six human cancer cell lines in addition to a normal human lung fibroblast (WI-38) were carried out. Cell viability was evaluated and both triterpenoids have not exerted any cytotoxicity on the tested normal cell line. Interestingly, compound $\mathbf{3}$ rather than $\mathbf{2}$ introduced a considerable antiproliferative effect against the tested colon cancer cell lines.
\end{abstract}

\section{INTRODUCTION}

Plant active metabolites are under intensive examinations globally to supplement the drugs with low indices of toxicity (AbdAlla et al., 2014, 2016; Favre et al., 2020; Shang et al., 2019). The secondary plant metabolites were reported to have the highest potentiality to provide the future drugs for the management of various diseases including inflammations, hypercholesterolemia,

\section{"Corresponding Author}

Howaida Ibrahim Abd-Alla, Chemistry of Natural Compounds Department, Pharmaceutical and Drug Industries Research Division, National Research Centre,Egypt.E-mail: howaida_nrc@yahoo.com hyperlipidemia, and immunosuppressive disorders, as well as diabetes (Aly et al., 2017; Shang et al., 2019).

Type 2 diabetes mellitus is described as a metabolic disorder characterized by several factors, including hyperglycemia and hyperlipidemia, resulting in increased reactive oxygen species and the formation of advanced glycation end products (AGEs) (Choudhury et al., 2018; Franco et al., 2017; Justino et al., 2018). At present, many treatments involving the use of antidiabetic agents derived from medicinal plants have been recommended. Their antidiabetic and inhibitory potential against enzymatic glycation of $\alpha$-amylase and $\alpha$-glucosidase, as well as nonenzymatic glycation and lipid peroxidation with low indices of toxicity, were reported (Choudhury et al., 2018; Justino et al., 2018). 
The genus Adonis L. (Ranunculaceae) comprises 32 annual or perennial herbaceous species (Hosseini et al., 2019; Shang et al., 2019). Due to the beauty of the flower, the plants of genus Adonis were used historically for ornamental purposes in some countries (Shang et al., 2019). Adonis species have long been used in European and Chinese folk medicine due to their cardiac-enhancing effects. To date, more than 130 chemical components have been isolated and identified from the genus Adonis (Shang et al., 2019). Except for cardiac glycosides, some flavones, carotenoids, and coumarins in the genus were also isolated and identified. They had very wide pharmacological activities, including antiangiogenic, anti-inflammatory, antioxidant, neuroprotective, and antiallergic properties (Shang et al., 2019). Little was published on other structural types such as terpenoids and more attention should be paid to these compounds. Adonis microcarpa DC within the 32 species has not been comprehensively studied. During our continued search for bioactive compounds with hypoglycemic properties from medicinal plants (Abd-Alla et al., 2014, 2016; Aly et al., 2016, 2017; Shaaban et al., 2018; Shalaby et al., 2014), we describe accordingly herein the isolation and structural determination of a pentahydric alcohol adonitol (1) and two pentacyclic triterpenoids lup-20(29)-en-3 $\beta$-ol (2) and 3 $\beta$-3-hydroxyolean12-en-28-oate (3) as well as three strophanthidin glycosides. Compound $\mathbf{1}$ was identified as a pentahydric sugar alcohol and is also known as xylitol or ribitol.

Xylitol, the nonnutritive sweetener, was reported recently (Deo et al., 2020) to reduce AGEs. The latter activity of this isolated compound encouraged us to examine the antiglycation properties of the major isolated pentacyclic triterpenoids: compounds $\mathbf{2}$ and 3. Alongside, the authors have evaluated their antiproliferative effects against six carcinoma cell lines. Their exerted cytotoxicity on the human lung fibroblast, the WI-38 cell line, was also examined as a model of a normal cell line. Inhibition of the major enzymes such as $\alpha$-amylase and $\alpha$-glucosidase is considered an essential approach to hyperglycemia treatment associated with type 2 diabetes (Oboh et al., 2014). Previous in vitro investigations evidenced the capability of compound 2 to inhibit $\alpha$-amylase and $\alpha$-glucosidase as well as aldose reductase taking into consideration that the compound was less potent against the $\alpha$-amylase enzyme (Ramu et al., 2014). On the other hand, compound $\mathbf{3}$ was found to be stronger against $\alpha$-glucosidase than $\alpha$-amylase (Zhang et al., 2017). Moreover, it was capable of inhibiting the later enzyme (Wang et al., 2010). The molecular docking study of compounds 2 and $\mathbf{3}$ using three enzymes was carried out to further confirm their efficiency as hypoglycemic agents.

\section{EXPERIMENTAL METHODS}

\section{Plant materials}

The above-ground parts of $A$. microcarpa DC (Ranunculaceae) at the flowering stages were harvested from the Northern Coast of Egypt, near Marsa Matrouh. The plant was identified by Dr. Mohamed El-Gebali, Taxonomy Specialist, ElOrman Botanical Garden at Giza. Authentic reference material is available at the Department of Chemistry of Natural Compounds. The plant was ground to powder substance after drying.

\section{Phytochemical investigation}

\section{General instrumental procedures}

The ultraviolet lamp $(\lambda \max =254$ and $330 \mathrm{~nm}$, Shimadzu (B), a product of Hanovia Lamps, was used for localization of spots on chromatograms. Kofler's heating stage microscope was used for the measurement of the melting point. UV: Shimadzu ${ }^{\circledR} U V$-visible spectrophotometer. nuclear magnetic resonance (NMR) spectra were recorded on Bruker Avance ${ }^{\circledR}$ DRX-400 Spectrophotometer and Varian-400 Spectrophotometers. EI-MS spectra were taken on HP MS-5988. $\delta$ values are reported as ppm relative to TMS in the convenient solvent. The X-ray instrument ENRAF Nonius FR 590 Kappa CCD single crystal diffractometer was used. $\alpha$-Radiation $(l$ $=0.71073 \AA$ ) was used with an X-ray tube, operated at $20 \mathrm{~mA} / 50$ $\mathrm{kV}$. The two-dimensional CCD detector measured the intensity of diffraction from the crystal. A microscope displayed the crystal on the $\mathrm{PC}$ monitor.

Solvent systems, spray reagents, and chromatographic techniques

High analytical grade chemicals from Sigma-Aldrich (St Louis, MO), Merck (Darmstadt, Germany), and Fluka (Buchs, Switzerland) were used. All solvents used for extraction and chromatographic separation were of analytical grade. Column chromatography (CC) was carried out using silica gel (Si) 60 (E. Merck) and Sephadex LH-20 (Pharmacia Fine Chemicals AB, Uppsala, Sweden). Thin-layer chromatography (TLC) was carried out on silica gel $60 \mathrm{~F}_{254}$-precoated aluminum plates $(0.2 \mathrm{~mm}$; Merck), and the solvent systems $\mathrm{S}_{1}$ : EtOAc/ $\mathrm{C}_{6} \mathrm{H}_{6}(0.5: 9.5), \mathrm{S}_{2}$ : EtOAc/ $\mathrm{C}_{6} \mathrm{H}_{6}(2: 9), \mathrm{S}_{3}:$ EtOAc/MeOH$/ \mathrm{H}_{2} \mathrm{O} / \mathrm{HOAc}(16: 2: 0.5: 0.5)$, and $\mathrm{S}_{4}: \mathrm{CHCl}_{3} / \mathrm{MeOH}(7: 3)$ were used. $R_{1}: p$-anisaldehyde-sulfuric acid, $R_{2}$ : sulfuric acid/methanol $(30 \%)$, followed by heating at $105^{\circ} \mathrm{C}$ for $1-2$ minutes for terpenes, and $R_{3}$ : Kedde's reagent ( $2 \%$ of 3,5-dinitrobenzoic acid in ethanol mixed equally with $1 \mathrm{~N}$ ethanolic potassium hydroxide) were used as spray reagents.

\section{Chemical characterization of $A$. microcarpa DC above-ground parts}

\section{Quantitative estimation of cardiac glycosides}

This was carried out using the UV-spectrophotometric method based on the analytical data using Kedde's reagent according to Solich et al. (1992) with some modifications.

\section{Preparation of sample}

The above-ground parts of $A$. microcarpa DC (10 g) were extracted with $100 \mathrm{ml}$ of methanol $(80 \%)$ under shaking at room temperature for 48 hours, followed by filtration through a centered glass funnel. Five $\mathrm{ml}$ of the extract was added to $15 \mathrm{ml}$ of distilled water and the resulting solution was treated with $2 \mathrm{ml}$ of freshly prepared lead acetate $(12.5 \%)$. The volume was adjusted to $25 \mathrm{ml}$ with distilled water and then filtered. The filtrate $(10 \mathrm{ml})$ was placed in a $25 \mathrm{ml}$ volumetric flask and $5 \mathrm{ml}$ of $4.7 \%$ disodium hydrogen phosphate solution was added, followed by filtration and the volume adjusted to $25 \mathrm{ml}$ by distilled water.

\section{Determination of the total cardiac glycosides}

The calibration curve of olitoriside based on Kedde's reagent was prepared as follows: olitoriside $(25 \mathrm{mg})$ was 
dissolved in spectroscopic methanol $(125 \mathrm{ml})$. A definite volume corresponding to $0.025,0.050$, and $0.10 \mathrm{mg}$ was completed to 25 $\mathrm{ml}$ with spectroscopic methanol. Freshly prepared Kedde's reagent $(2 \mathrm{ml})$ was added to the prepared solution of olitoriside $(2 \mathrm{ml})$. The mixture was kept at room temperature for 5 minutes, whereby a pink color developed. The absorption maximum was measured at $l_{\max } 560 \mathrm{~nm}$, against a blank of Kedde's reagent $(2 \mathrm{ml})$ mixed with methanol $(2 \mathrm{ml})$. The average of three measurements was taken for each concentration. A volume $(2 \mathrm{ml})$ of the purified extract of A. microcarpa was mixed with methanolic 3,5-dinitrobenzoic acid $(2 \%, 1 \mathrm{ml})$ and the methanolic potassium hydroxide $(1 \mathrm{~N}, 1 \mathrm{ml})$. The absorption maximum was measured after 5 minutes at $1_{\max } 560$ $\mathrm{nm}$. An average of three measurements was taken for the extract.

\section{Extraction, isolation, and purification of compounds}

The air-dried powdered above-ground parts (900 g) were exhaustively extracted with $80 \%$ aqueous methanol $(3 \times$ 1.2 1) at room temperature. The combined methanolic extract was concentrated to 21 under reduced pressure at $50^{\circ} \mathrm{C}$ and left overnight at room temperature. The precipitate formed was filtered off, then dissolved in the least amount of methanol, and left overnight at room temperature. A white precipitate was formed, which was separated by filtration and recrystallized from methanol to give rise to $25 \mathrm{mg}$ of pure compound $\mathbf{1}$.

The mother liquor was dried under a vacuum at $50^{\circ} \mathrm{C}$ to give rise to $27 \mathrm{~g}$ of oily brownish residue. The residue was resolved on CC using Si 60 (300 g, $80 \times 1.5 \mathrm{~cm})$ as an adsorbent and eluted first with dichloromethane, followed by a gradual increase of methanol proportions. The fractionation was monitored using TLC and similar fractions (each $50 \mathrm{ml}$ ) were combined and freed from the solvent. The chromatogram was visualized using UV (254/365 $\mathrm{nm}$ ) and consequent spraying with $R_{1}$ and $R_{2}$ for compounds 1-3 and $R_{3}$ and $R_{4}$ for compounds 4-6. Three fractions were separated: fraction I (450 mg) was eluted with dichloromethane/ methanol $(90: 10 v / v)$, while fraction II (1.8 g) was separated with dichloromethane/methanol (80:20 v/v) and finally fraction III (145 $\mathrm{mg}$ ) with dichloromethane/methanol (70:30).

Fraction I was chromatographed on Si CC $(90 \times 1.5 \mathrm{~cm})$ and eluted first with toluene/EtOAc $(9.5: 0.5 \mathrm{v} / \mathrm{v})$ to give rise to crude compound 2 , which was purified by crystallization from methanol/ethyl acetate mixture to give $34 \mathrm{mg}$ yield. Compound 3 $(60 \mathrm{mg})$ was eluted with toluene/EtOAc $(9: 1 \mathrm{v} / \mathrm{v})$ and crystallized from ethyl acetate.

Fraction II was subjected to Sephadex LH-20 (118 g, 75 $\times 2 \mathrm{~cm}, \mathrm{MeOH}) \mathrm{CC}$ to give rise to $158 \mathrm{mg}$ of a crude mixture of compounds 4 and $\mathbf{5}$. The mixture was subjected to RP-18 CC $(15 \times$ $0.5 \mathrm{~cm}$ ) connected with a prostatic pump with a flow rate of $5 \mathrm{ml} /$ minutes and eluted with $50 \% \mathrm{MeOH} / \mathrm{H}_{2} \mathrm{O}$. The fractionation was monitored by TLC, where similar fractions were collected to give rise to two subfractions A and B. Subfraction A was crystallized from $\mathrm{MeOH} / \mathrm{EtOAc}$ to give $13 \mathrm{mg}$ of pure compound 4 . Subfraction B (18 mg) was separated as a mixture of two compounds (ca 2:1): 4 and $\mathbf{5}$, respectively.

Fraction III was rechromatographed on Si CC (250 g, 75 $\times 2 \mathrm{~cm}) \mathrm{CC}$ and eluted with dichloromethane/methanol $(85: 15)$ to give rise to $11 \mathrm{mg}$ of compound $\mathbf{6}$, which was crystallized from methanol/diethyl ether.
The chemical structures of the separated compounds were identified by the application of spectroscopic methods of $1 \mathrm{H}$ and ${ }^{13} \mathrm{C}$ NMR (Fig. 1 and 2).

Adonitol (1)

M.p. $85^{\circ} \mathrm{C}-90^{\circ} \mathrm{C},{ }^{1} \mathrm{H}$ NMR dimethyl sulfoxide [(DMSO) $\left.-d_{6}\right]: 4.54(\mathrm{~s}, 3 \mathrm{H}), 4.48$ and $4.31(5 \mathrm{OH}) ; 3.59-3.49\left(\mathrm{~m}, 2 \mathrm{CH}_{2}\right)$; 3.42-3.34 ( $m, 3 \mathrm{CH})$ ppm and ${ }^{13} \mathrm{C}$ NMR: $72.75(3 \mathrm{CH}) ; 63.02(2$ $\left.\mathrm{CH}_{2}\right) \mathrm{ppm}$. The structure was confirmed by X-ray crystallography (Fig. 2).

Lup-20(29)-en-3 $\beta$-ol (2)

$\mathrm{C}_{30} \mathrm{H}_{50} \mathrm{O}$ white crystalline needles; m.p.: $210^{\circ} \mathrm{C}-212^{\circ} \mathrm{C}$; $R$ f: 0.84 (2:9, EtOAc/ $\left.{ }_{6} \mathrm{H}_{6}\right) ; \mathrm{C}_{30} \mathrm{H}_{50} \mathrm{O} .{ }^{1} \mathrm{H} \mathrm{NMR}\left(\mathrm{CDCl}_{3}, 300 \mathrm{MHz}\right)$ : 4.70 and $4.52\left(2 \mathrm{H}, \mathrm{m}, \mathrm{CH}_{2}-29\right), 3.22(1 \mathrm{H}, \mathrm{dd}, \mathrm{H}-3), 2.42(1 \mathrm{H}, \mathrm{m}$, $\mathrm{H}-19 \alpha), 1.92$ (1H, m, H-21 $), 1.72\left(3 \mathrm{H}, \mathrm{s}, \mathrm{CH}_{3}-30\right), 1.46(1 \mathrm{H}, \mathrm{m}$, $\mathrm{H}-21 \beta), 1.05$ (3H, s, $\left.\mathrm{CH}_{3}-26\right), 0.97$ (3H, s, $\left.\mathrm{CH}_{3}-23\right), 0.98$ (3H, s, $\left.\mathrm{CH}_{3}-27\right), 0.90\left(3 \mathrm{H}, \mathrm{s}, \mathrm{CH}_{3}-25\right), 0.86(3 \mathrm{H}, \mathrm{s}, \mathrm{CH} 3-28), 0.82(3 \mathrm{H}$, $\left.\mathrm{s}, \mathrm{CH}_{3}-24\right) ;{ }^{13} \mathrm{C} \mathrm{NMR}\left(\mathrm{CDCl}_{3}, 75 \mathrm{MHz}\right): 150.8(\mathrm{C}-20), 109.4(\mathrm{C}-$ 29), 79.2 (C-3), 55.6 (C-5), 50.1 (C-9), 48.0 (C-18), 48.0 (C-19), 42.8 (C-17), 42.5 (C-14), 41.2 (C-8), 40.2 (C-22), 39.0 (C-4), 38.7 (C-1), 38.1 (C-13), 37.3 (C-10), 35.4 (C-16), 34.2 (C-7), 29.2 (C21), 27.6 ( $\left.\mathrm{CH}_{3}-23\right), 27.7$ (C-2/15), 25.6 (C-12), 21.6 (C-11), 19.2 $\left(\mathrm{CH}_{3}-30\right), 18.2(\mathrm{C}-6), 17.5\left(\mathrm{CH}_{3}-28\right), 16.0\left(2 \mathrm{CH}_{3}-25 / 26\right), 15.3$ $\left(\mathrm{CH}_{3}-24\right), 14.2\left(\mathrm{CH}_{3}-27\right)$.

\section{3 $\beta$-3-Hydroxyolean-12-en-28-oate (3)}

${ }^{1} \mathrm{H}$ NMR $\left(\mathrm{CDCl}_{3}, 400 \mathrm{MHz}\right): \delta 1.53-1.55(1 \mathrm{H}, \mathrm{m}, \mathrm{C} 1-$ $\mathrm{H}), 1.22-1.24(1 \mathrm{H}, \mathrm{m}, \mathrm{C} 2-\mathrm{H}), 3.37(1 \mathrm{H}, \mathrm{dd}, \mathrm{C} 3-\mathrm{H}), 0.72(1 \mathrm{H}, b s$, C5-,H) 1.32-1.35 and 1.46-1.490 (1H, m, C6-H), 1.35-1.40 (1H, $\mathrm{m}, \mathrm{C} 7-\mathrm{H}), 1.52-1.56$ (1H, m, C-9), 1.90-1.92 (1H, m, C11-H), $5.25(1 \mathrm{H}, b s, \mathrm{C} 12-\mathrm{H}), 1.60-1.63$ and $1.06-1.10(1 \mathrm{H}, \mathrm{m}, \mathrm{C} 15-\mathrm{H})$, $1.80-1.83$ and $1.02-1.06(1 \mathrm{H}, \mathrm{m}, \mathrm{C} 16-\mathrm{H}), 2.81(1 \mathrm{H}, \mathrm{dd}, \mathrm{C} 18-\mathrm{H})$, $1.54-1.62(1 \mathrm{H}, \mathrm{m}, \mathrm{C} 19-\mathrm{H}), 1.32-1.42(1 \mathrm{H}, \mathrm{m}, \mathrm{C} 21-\mathrm{H}), 1.51-1.55$ and $1.72-1.77(1 \mathrm{H}, \mathrm{m}, \mathrm{C} 22-\mathrm{H}), 1.4\left(3 \mathrm{H}, \mathrm{s}, \mathrm{C} 23-\mathrm{CH}_{3}\right), 0.96(3 \mathrm{H}$, $\left.\mathrm{s}, \mathrm{C} 24-\mathrm{CH}_{3}\right), 0.89\left(3 \mathrm{H}, \mathrm{s}, \mathrm{C} 25-\mathrm{CH}_{3}\right), 0.84\left(3 \mathrm{H}, \mathrm{s}, \mathrm{C} 26-\mathrm{CH}_{3}\right), 1.30$ $\left(3 \mathrm{H}, \mathrm{s}, \mathrm{C} 27-\mathrm{CH}_{3}\right), 0.94\left(3 \mathrm{H}, \mathrm{s}, \mathrm{C} 29-\mathrm{CH}_{2}\right), 0.98\left(3 \mathrm{H}, \mathrm{s}, \mathrm{C} 30-\mathrm{CH}_{3}\right)$ ppm, ${ }^{13} \mathrm{C} \mathrm{NMR}\left(\mathrm{CDCl}_{3}, 100 \mathrm{MHz}\right): d 38.4$ (C-1), 27.1 (C-2), 78.6 (C-3), 38.4 (C-4), 55.5 (C-5), 18.2 (C-6), 32.6 (C-7), 9.6 (C-8), 48.2 (C-9), 37.1 (C-10), 23.5 (C-11), 122.5 (C-12), 143.9 (C-13), 41.5 (C-14), 27.72 (C-15), 32.1 (C-16), 46.3 (C-17), 41.4 (C-18), 46.4 (C-19), 30.61 (C-20), 33.5 (C-21), 331.7 (C-22), $28.2\left(\mathrm{CH}_{-}-\right.$ 23), $15.6\left(\mathrm{CH}_{3}-24\right), 15.4\left(\mathrm{CH}_{3}-25\right), 16.7\left(\mathrm{CH}_{3}-26\right), 25.7\left(\mathrm{CH}_{3}-27\right)$, $183.1\left(\mathrm{CH}_{3}-28\right), 183.9$ (C-28), 33.3 (C-29), $23.6\left(\mathrm{CH}_{3}-30\right)$.

\section{Strophanthidin glycosides (4-6)}

The ${ }^{1} \mathrm{H}$ NMR and ${ }^{13} \mathrm{C}$ NMR resonance assignments of strophanthidin-3- $O$ - $\beta$-D-glucopyranosyl- $(\mathbf{1} \rightarrow \mathbf{4})-\beta$-D-digitoxoside (4), strophanthidin-3-O- $\beta$-glucopyranosyl-(1 $\rightarrow$ 4)- $\beta$-boiviopyranoside $(5)$ and gluco- $(\mathbf{1} \rightarrow \mathbf{6})$-strophanthidin-3-O- $\beta$-glucopyranosyl- $(\mathbf{1} \rightarrow \mathbf{4})-\beta$ boiviopyranoside (6) are illustrated in Table 1.

\section{Biological activities}

All chemicals served in the antiglycation assay were of analytical grade (Sigma, Serva, and Lonza). Cell culture assay was carried out depending on aseptic conditions using sterile plastics (Greiner) and reagents (Lonza and Sigma) of tissue culture grade. 


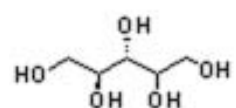

1

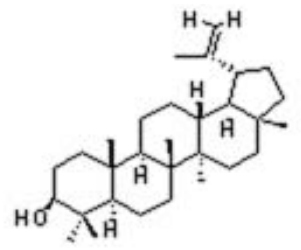

2<smiles>CC1(C)CCC2(C(=O)O)CCC3C4CC5C(CCC3C2C1)C4CCC(O)C5(C)C</smiles>

3

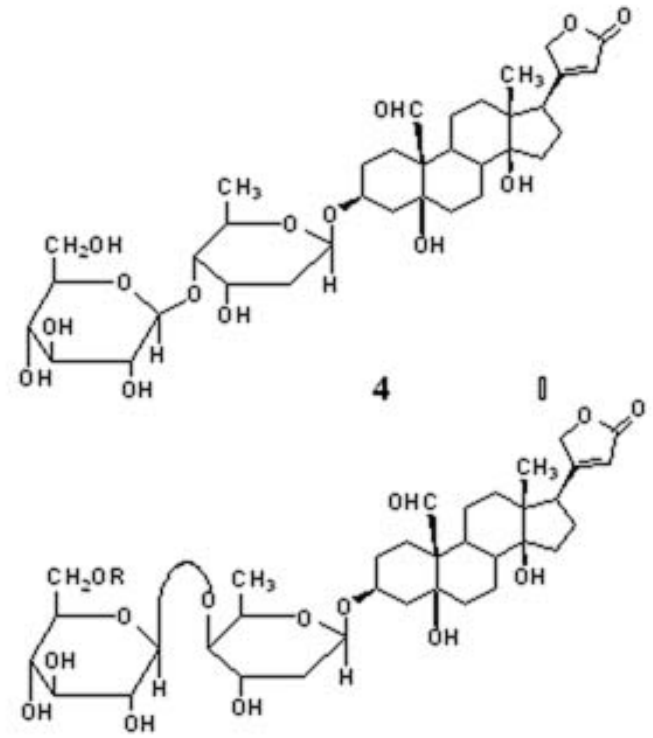

$$
\begin{array}{ll}
5 & (\mathrm{R}=\mathrm{H}) \\
6 & (\mathrm{R}=\beta \text {-D-glucopyranoasy })
\end{array}
$$

Figure 1. Structure of isolated compounds from aqueous methanolic extract of the above-ground parts of $A$. microcarpa DC (Ranunculaceae).

\section{Antiglycation assay}

The assay was carried out according to Matsuura et al. (2002) following the modified method of Shaaban et al. (2018). Compounds' stock solutions and rutin, the glycated inhibitor standard, were prepared as $20 \times$ of the required tested concentration in DMSO before starting the assay. Determining the effective concentration for $50 \%$ glycation inhibition $\left(\mathrm{EC}_{50}\right)$ was recorded from the nonlinear regression analysis.

\section{Antiproliferation assay}

Cultures of six cancer and normal lung cell lines

Six human cancer cell lines were used to examine the ability of compounds $\mathbf{2}$ and $\mathbf{3}$ to inhibit the growth of incubated cancer cells. The cancer cell line panel was human type from the American Type and Culture Collection (ATCC), except Huh cells: two breast: MCF-7 (ATCC ${ }^{\circledR} \mathrm{HTB}-22^{\mathrm{TM}}$ ) and MDA-MB-231 (ATCC ${ }^{\circledR}$ CRM-HTB-26 ${ }^{\mathrm{TM}}$ ), two colorectal: Caco-2 (ATCC ${ }^{\circledR}$ HTB$37^{\mathrm{TM}}$ ) and HCT-116 (ATCC ${ }^{\circledR}$ CCL-247 ${ }^{\mathrm{TM}}$ ), and two liver: Huh-7 (Vacsera, Egypt) and HepG2 (ATCC $®$ HB-8065 ${ }^{\mathrm{TM}}$ ). In addition, the lung WI-38 (ATCC ${ }^{\circledR}$ CCL-75 ${ }^{\mathrm{TM}}$ ) cell line was the selected model to examine the cytotoxicity effects of the compounds on normal cells.

In vitro screening of the antiproliferation properties of compounds 2 and 3

Compounds 2 and $\mathbf{3}$ together with the standards and DMSO vehicle were incubated separately, with each cell line to get their $\mathrm{GI}_{50}$. All cell lines were cultured in Dulbecco's modified Eagle's medium supplemented with $2 \mathrm{mM}$ L-glutamine and $10 \%$ fetal bovine serum (FBS) except MCF-7 cells. Moreover, 1\% non-essential amino acid (NEAA), $100 \mathrm{U} / \mathrm{ml}$ penicillin, and 100 $\mu \mathrm{g} / \mathrm{ml}$ streptomycin sulfate were also added to the culture growth media. The basic medium of MCF-7 culture was Roswell Park Memorial Institute RPMI 1640, while the same supplements as above that were supplied lacked 1\% NEAA. The routine maintenance of each cell type as well as the prepared stocks of the tested compounds followed our experience in the drug discovery field (Galal et al., 2018; Shaaban et al., 2018). In brief, $40 \mathrm{mM}$ stock solution in DMSO was separately prepared from every compound while being stored under dry condition. Simultaneous 


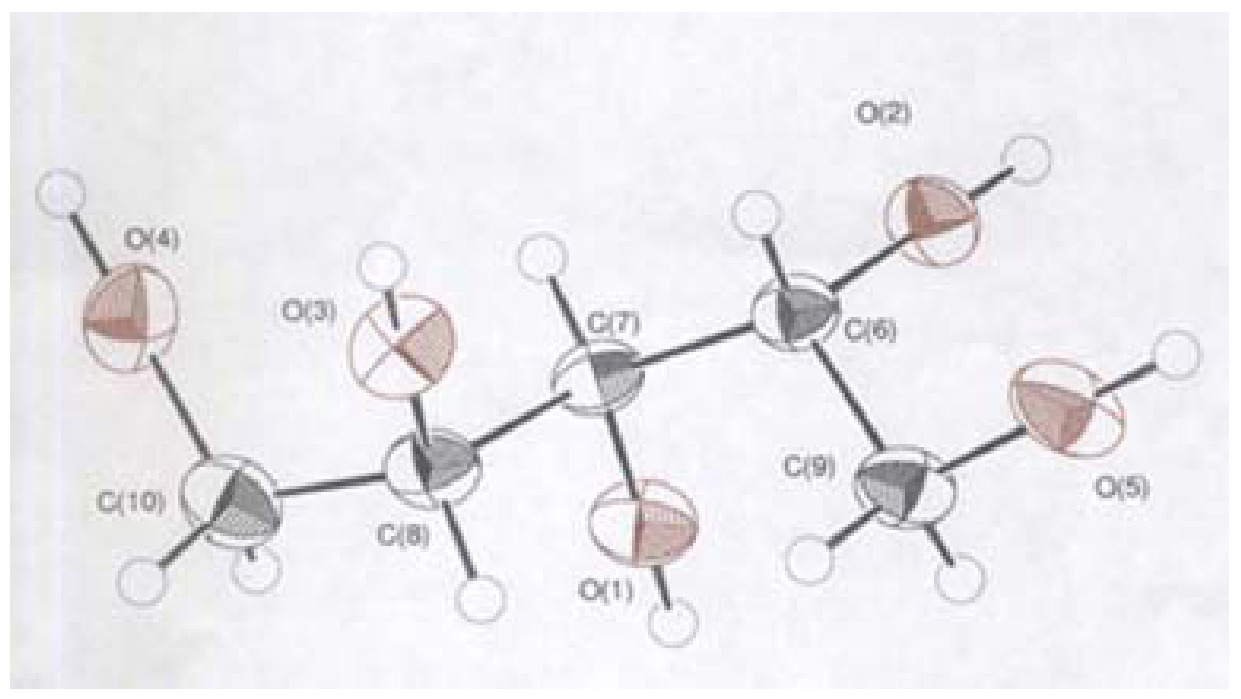

Figure 2. X-ray crystal structure determination of compound 1.

dilutions from the stocks were continued into the culture growth medium free of FBS before the incubation with the cancer cell type. The sulforhodamine-B (SRB) assay (Vichai and Kirtikara, 2006) was followed but differed in the SRB concentration $(0.01 \%)$. Colchicine (BDH Laboratory Supplies) and Adricin (doxorubicin-hydrochloride) from the Company of United EIMC were the positive controls against cancer cells, while cisplatin (Mylan, Saint Priest, France) was the examined standard against the WI-38 cell.

\section{Statistical analysis}

Experimental results were analyzed in duplicate and expressed as means \pm standard error of the mean (SEM). The concentrations of getting $50 \%$ of the activity $\left(\mathrm{EC}_{50}, \mathrm{CC}_{50}\right.$ and $\left.\mathrm{GI}_{50}\right)$ were calculated using the nonlinear regression fitting model of GraphPad Prism 6.0 Software.

\section{In silico study on the antidiabetic enzymes}

The files corresponding to the 3D structure of the enzymes used in docking studies were downloaded from the Protein Data Bank: $\alpha$-glucosidase, PDB code: 5NN8 (RoigZamboni et al., 2017); $\alpha$-amylase, PDB code: 2QV4 (Maurus et al., 2008); and aldose reductase, PDB code: 4YS1 (Rechlin et al., 2017). The PDB files of proteins were prepared using VEGA ZZ 3.0.5 (Pedretti et al., 2003) by deleting the native ligand, water, and unwanted co-crystallized compounds. The native ligands, compound $\mathbf{2}$ and compound $\mathbf{3}$, were designed by ChemBio3D Ultra 14.0, followed by VEGA ZZ 3.0.5, for performing energy minimization applying the Molecular Orbital PACkage protocol. The docking process was conducted by automated docking software AutoDock Vina 1.0.3 (Trott and Olson, 2010). The grid box was adjusted for $\alpha$-glucosidase in dimensions of $30 \times 30 \times 30$ $\AA$ and the space coordinates were $X=-14.84, Y=-38.55$, and $Z=$ 93.4. Three-dimensional positioning of the grid box for $\alpha$-amylase was $X=10.77, Y=44.50$, and $Z=27.11$ and the size was $26 \times 26 \times$ $26 \AA$, respectively. The geometrical shape of the interaction site in the case of aldose reductase was rectangular with dimensions equal to $17.2,16.3$, and 27.2 for $X, Y$, and $Z$, respectively. It was centered at $X=69.1, Y=-7.21$, and $Z=47.12$ in the space. The PyMOL 2.3.2 software was used for visualization (Schrodinger, 2015).

In silico absorption, distribution, metabolism, excretion, and toxicity (ADMET) prediction of the isolated compounds

In silico physicochemical properties (ADMET, of the isolated compounds were predicted using the Swiss ADME website (Daina et al., 2017) and ADMET SAR website (Cheng et al., 2012)

\section{RESULTS AND DISCUSSION}

\section{Chemical characterization}

Phytochemical analysis of $A$. microcarpa DC aboveground parts led to the isolation of pure bioactive compounds 1-6 (Fig. 1). All the compounds are isolated for the first time from this species. The three strophanthidin glycosides 4-6 were previously isolated from Adonis mongolica (Thieme and Lamzhav, 1976).

The structure of compound $\mathbf{1}$ was confirmed by X-ray crystallography (Fig. 2) as the pentahydric alcohol adonitol. Adonitol is also known as xylitol or ribitol and can be found in nature in many vegetables, fruits, oats, and mushrooms and is produced in small quantities in the human organism. It was previously isolated from many Adonis spp. such as Adonis coerulea, Adonis leiosepala, and A. mongolica (Evdokimov, 1979; Zhang et al., 1991).

The ${ }^{1} \mathrm{H}$ NMR spectrum of compound $\mathbf{2}$ showed the seven sharp singlets assigned to the protons of tertiary methyl groups. The two multiplets that could be ascribed to a methylene group at C-29 appeared. Compounds $\mathbf{2}$ and $\mathbf{3}$ were identified and their structures were confirmed by comparison with published data as pentacyclic triterpenoid lup-20(29)-en-3 $\beta$-ol (Menezes-de-Oliveira et al., 2011) and 3 $\beta$-3-hydroxyolean-12-en-28-oate 3 (Mahato and Kundu, 1994).

The aglycone part of compounds 4-6 was identified as strophanthidin based on the carbon signals of the $\alpha, \beta$ - 
Table 1. ${ }^{1} \mathrm{H}(400 \mathrm{MHz})$ and ${ }^{13} \mathrm{C}(100 \mathrm{MHz}) \mathrm{NMR}$ data of strophanthidin glycosides (4-6).

\begin{tabular}{|c|c|c|c|c|c|c|c|c|c|c|c|c|c|}
\hline \multicolumn{8}{|c|}{ Aglycone moiety } & \multicolumn{6}{|c|}{ Sugar moiety } \\
\hline \multirow[t]{3}{*}{ Position } & \multicolumn{4}{|c|}{$\delta \mathbf{H}$} & \multicolumn{3}{|c|}{$\delta \mathrm{C}$} & \multirow[t]{2}{*}{ Position } & \multicolumn{4}{|c|}{$\delta \mathbf{H}$} & \multirow{2}{*}{$\begin{array}{l}\delta \mathrm{C} \\
(4)\end{array}$} \\
\hline & \multirow{2}{*}{\multicolumn{2}{|c|}{ (4) }} & \multirow{2}{*}{\multicolumn{2}{|c|}{ (6) }} & \multirow[t]{2}{*}{ (4) } & \multirow[t]{2}{*}{ (4) and (5) } & \multirow[t]{2}{*}{ (6) } & & \multicolumn{2}{|c|}{ (4) } & \multicolumn{2}{|r|}{ (6) } & \\
\hline & & & & & & & & \multicolumn{6}{|c|}{ Glycone -1 } \\
\hline \multirow[t]{2}{*}{1} & $a$ & 2.04 & $a$ & 2.14 & 25.92 & 24.18 & 25.32 & $1^{\prime}$ & $\alpha$ & 5.01 & & 4.88 & 99.10 \\
\hline & $\beta$ & 1.40 & $\beta$ & 1.32 & & & & & & & & & \\
\hline \multirow[t]{2}{*}{2} & $\alpha$ & 1.67 & $\alpha$ & 1.60 & 25.20 & 25.26 & 26.04 & $2^{\prime}$ & $\alpha$ & 1.80 & $\alpha$ & 1.72 & 37.15 \\
\hline & $\beta$ & 2.05 & $\beta$ & 1.96 & & & & & $\beta$ & 2.04 & $\beta$ & 1.96 & \\
\hline 3 & $\alpha$ & 4.26 & $\alpha$ & 4.18 & 76.39 & 74.94 & 76.460 & $3^{\prime}$ & $\beta$ & 4.22 & & 4.13 & 66.60 \\
\hline \multirow[t]{2}{*}{4} & $\alpha$ & 1.69 & $\alpha$ & 1.58 & 36.85 & 35.72 & 37.02 & $4^{\prime}$ & $\alpha$ & 3.52 & & 3.47 & 76.38 \\
\hline & $\beta$ & 2.18 & $\beta$ & 2.18 & & & & & & & & & \\
\hline 5 & & & & & 75.26 & 75.32 & 75.37 & $5^{\prime}$ & $\alpha$ & 4.15 & & 4.06 & 70.37 \\
\hline \multirow[t]{2}{*}{6} & $\alpha$ & 1.72 & $\alpha$ & 1.63 & 37.19 & 39.04 & 37.34 & $6^{\prime}$ & & 0.98 & & 1.25 & 17.24 \\
\hline & $\beta$ & 2.19 & $\beta$ & 2.10 & & & & & & Glyc & $e-2$ & & \\
\hline \multirow[t]{2}{*}{7} & $\alpha$ & 1.77 & $\alpha$ & 2.13 & 18.94 & 19.03 & 19.03 & & & & & & \\
\hline & & & $\beta$ & 1.69 & & & & & & & & & \\
\hline 8 & $\beta$ & 2.04 & $\beta$ & 1.96 & 42.56 & 42.72 & 42.72 & & & & & & \\
\hline 9 & $\alpha$ & 1.49 & $\alpha$ & 1.71 & 40.50 & 40.34 & 40.48 & & & & & & \\
\hline 10 & & & & - & 54.78 & 56.22 & 56.33 & $1^{\prime \prime}$ & $\alpha$ & 4.40 & & 4.32 & 102.44 \\
\hline \multirow[t]{2}{*}{11} & $\alpha$ & 1.65 & $\alpha$ & 1.51 & 23.27 & 23.42 & 23.42 & $2^{\prime \prime}$ & $\beta$ & 3.34 & & 3.23 & 75.92 \\
\hline & $\beta$ & 1.37 & $\beta$ & 1.22 & & & & $3^{\prime \prime}$ & $\alpha$ & 3.37 & & 3.36 & 78.12 \\
\hline \multirow[t]{2}{*}{12} & $\alpha$ & 1.57 & $\alpha$ & 1.46 & 40.40 & 40.16 & 40.58 & $4^{\prime \prime}$ & $\beta$ & 3.39 & & 3.30 & 72.01 \\
\hline & $\beta$ & 1.61 & $\beta$ & 1.50 & & & & $5^{\prime \prime}$ & $\alpha$ & 3.47 & & 3.47 & 78.04 \\
\hline 13 & & & & - & 50.82 & 50.79 & 50.32 & $6^{\prime \prime}$ & $\alpha$ & 3.98 & $\alpha$ & 4.12 & 63.02 \\
\hline 14 & & & & - & 86.14 & 86.02 & 86.08 & & $\beta$ & 3.75 & $\beta$ & 3.76 & \\
\hline \multirow[t]{2}{*}{15} & $\alpha$ & 2.12 & & & 32.42 & 32.52 & 32.52 & & & & & & \\
\hline & $\beta$ & 1.80 & & & & & & & & & & & \\
\hline 16 & $\alpha$ & 1.96 & $\alpha$ & 2.18 & 27.94 & 28.04 & 28.04 & & & & & & \\
\hline & $\beta$ & 1.96 & $\beta$ & 1.90 & & & & glc- $1^{\prime \prime \prime}$ & & & & 4.40 & \\
\hline 17 & $\alpha$ & 2.90 & $\alpha$ & 2.90 & 51.92 & 51.87 & 51.89 & $2^{\prime \prime \prime}$ & & & & 3.22 & \\
\hline 18 & & 0.92 & & 0.86 & 16.18 & 16.27 & 16.29 & $3^{\prime \prime \prime}$ & & & & 3.36 & \\
\hline 19 & & 9.14 & & 10.05 & 210.02 & 210.03 & 210.02 & $4^{\prime \prime \prime}$ & & & & 3.28 & \\
\hline 20 & $\beta$ & - & $\beta$ & - & 178.32 & 178.33 & 178.33 & $5^{\prime \prime \prime}$ & & & & 3.22 & \\
\hline 21 & $\alpha$ & 5.14 & $\alpha$ & 5.04 & 75.23 & 75.40 & 75.38 & $6^{\prime \prime \prime}$ & & & $\alpha$ & 3.88 & \\
\hline & $\beta$ & 4.50 & $\beta$ & 4.93 & & & & & & & $\beta$ & 3.68 & \\
\hline 22 & & 5.98 & & 6.00 & 117.94 & 118.00 & 117.98 & & & & & & \\
\hline 23 & & - & & - & 177.32 & 178.27 & 177.34 & & & & & & \\
\hline
\end{tabular}

$\mathrm{dig}=$ digitoxose Biov = Biovinose; $\mathrm{glc}=$ glucose; Glycone- $1=$ digitoxose for compound $\mathbf{4}$ and Biovinose for compound $\mathbf{6}$; Glycone- $2=$ glucose for each of compounds 4 and 6; Boivinose $=J_{1,2 \mathrm{a}}=9.6 ; J_{1,2 \mathrm{~b}}=2.3 ;{ }^{2} J_{2 \mathrm{a}, 2 \mathrm{~b}}=12.6 ; J_{2 \mathrm{a}, 3}=J_{2 \mathrm{~b}, 3}=J_{3,4}=3.0 ; J_{4,5}=1.5 ; J_{5,6}=6.6 \mathrm{~Hz}$. Glucose: $J_{1,2}=7.6 ; J_{2,3}=J_{3,4}=J_{4,5}=$ $9.6 ; J_{5,6}=2.1 ; J_{5,6 \mathrm{~b}}=6.5 ;{ }^{2} J_{6 \mathrm{a}, 6 \mathrm{~b}}=12.1 \mathrm{~Hz}$.

unsaturated- $\gamma$-lactone ring. The presence of a quaternary carbon signal suggested the presence of a hydroxyl group at C-5. Also, the presence of a hydroxyl group at C-14 was established by the presence of a quaternary carbon signal. Finally, the presence of a methyl group signal (C-18) and aldehyde group signal (C-19) confirms the strophanthidin structure of the three compounds. The other carbon signals were found to be at the expected chemical shifts (Table 1). Some proton signals (Table 1) were assigned based on the corresponding carbon signals in the heteronuclear multiple quantum coherence (HMQC) spectrum. Compound 4 was identified as strophanthidin-3-O- $\beta$-D-glucopyranosyl-( $(1 \rightarrow 4)$ $\beta$-D-digitoxoside (Fig. 1) from its spectroscopic one- and twodimensional NMR and comparing its spectroscopic published data (Mahato and Kundu, 1994; Yoshikawa et al., 1998). The position of the digitoxose at $\mathrm{C}-3$ of strophanthidin in compound 4 was confirmed by the cross-peaks $\mathrm{C}-3 / \mathrm{H}-1^{\prime}$ and $\mathrm{C}-1^{\prime} / \mathrm{H}-3$. Also, the attachment of the glucose with the digitoxose at $\mathrm{C}-4$ was confirmed by the cross-peaks $\mathrm{C}-4^{\prime} / \mathrm{H}-1^{\prime \prime}$ and $\mathrm{C}-1^{\prime \prime} / \mathrm{H}-4$ " in its heteronuclear 
multiple bond correlation (HMBC) spectrum. Compound 5 was obtained as a mixture with compound $\mathbf{4}$ ( $c a 1: 2$, resp.). The mixture showed a positive test for cardiac glycosides using Kedde's reagent. Both compounds $\mathbf{4}$ and $\mathbf{5}$ have the same aglycone but the first sugar of each compound has C-4 of different stereochemistry that was confirmed by ${ }^{13} \mathrm{C} \mathrm{NMR}$ and distortionless enhancement by polarization transfer (DEPT) spectra (Islam et al., 2013; Mahato and Kundu, 1994; Yoshikawa et al., 1998). The chemical structures of compounds $\mathbf{4}$ and $\mathbf{5}$ were unambiguously assigned based on one-dimensional (1D) and two-dimensional (2D) NMR of ${ }^{1} \mathrm{H},{ }^{13} \mathrm{C}$, DEPT, HMQC, and HMBC (Lei et al., 1996; Mahato and Kundu, 1994). Compound 5 was identified as strophanthidin-3-O$\beta$-glucopyranosyl-( $(1 \rightarrow 4)-\beta$-boiviopyranoside. Also, gluco- $(1 \rightarrow 6)$ strophanthidin 3-O- $\beta$-glucopyranosyl- $(1 \rightarrow 4)$ - $\beta$-boiviopyranoside 6 (Thieme and Lamzhav, 1976) was identified and confirmed by comparison with data in previous literature.

Previous studies have reported other compounds identified in Adonis spp., e.g., k-strophanthin B, cymarin, adonitoxin, acetyladonitoxin, vernadigin, strophadogenin, and strophanthidin (Shang et al., 2019). Cardiac glycosides are important active compounds of the genus Adonis. Therefore, a quantitative estimation of the total cardiac glycoside content of the investigated species $A$. microcarpa DC would be necessary. This was carried out using the UV-spectrophotometric method based on the analytical data using Kedde's reagent and its percentage was found to be 0.52 .

\section{Biological activities}

The present study was extended to investigate the antiglycation activities and antiproliferative properties against six cancer cell lines of the major triterpenoids isolated from $A$. microcarpa DC (Ranunculaceae).

The capability of several medicinal plants to inhibit many of the embroiled enzymes implicated in the pathogenesis of diabetes has been evidenced (Choudhury et al., 2018). Elevation of glucose levels in the blood of diabetic patients most likely results in the higher detection of glycated hemoglobin ( $\mathrm{HbAlc})$ (Choudhury et al., 2018). A minor amount of HbAlc was detected in normal blood indices. However, its percentage is accelerated by the increment of serum glucose (Leow, 2016). Generally, amino groups of proteins (e.g., HbA1c) and their metabolites, peptides and amino acids are nonenzymatic glycosylate by reduced sugars eventually resulted in forming insoluble complexes known as AGEs. Hence, the accumulation of AGEs becomes responsible for a versatile complication in diabetes mellitus and the etiology of aging disorders (Choudhury et al., 2018) as well. Fortunately, testing the capacity of a compound to directly suppress the glycated proteins is available by the in vitro antiglycation assay (Matsuura et al., 2002).

Compound $\mathbf{2}$ which is a dietary triterpene, previously isolated from Zanthoxylum conspersipunctatum, was reported to have diverse biological effects, including anti-inflammatory, antidiabetic, and antitumor (Ahmed et al., 2011; Choudhury et al., 2018). In our study, compound 2 was completely able to inhibit AGEs formation while $\mathrm{EC}_{50}(26.5 \mu \mathrm{M})$ was interestingly comparable to rutin $\left(\mathrm{EC}_{50}=26.0 \mu \mathrm{M}\right)$. In a separate in vitro study by our team, we did not record any toxicity against Vero cells or hTERT-RPE1 at its recorded bioactive concentration range (AbdAlla et al., 2021). Besides, our results in the present study against the fibroblast normal lung cells (WI-38) did not record any toxicity up to $50 \mu \mathrm{M}$, the highest applied concentration (Table 3).

On the other hand, the activity of oleanolic acid as an antiglycation agent was previously evidenced (Choudhury et al., 2018). Compound 3 (3 $\beta$-3-hydroxyolean-12-en-28-oate) was able to completely suppress the formed glycation down to $25 \mu \mathrm{M}$ (Table 2). It exerted cytotoxicity against the normal lung cell line displaying $\mathrm{EC}_{50}=57.44 \pm 2.0$ while $25 \mu \mathrm{M}$ was the maximum nontoxic concentration (Table 3 ).

Table 2. Evaluation of the antiglycation capacities of compounds $\mathbf{2}$ and $\mathbf{3}$ isolated from A. microcarpa DC. above-ground parts.

\begin{tabular}{|c|c|}
\hline Compound & $\mathrm{EC}_{50} \pm \mathrm{SEM}$ \\
\hline 2 (Lup-20(29)-en-3ß-ol) & $26.5 \pm 2.4 \mu \mathrm{M}$ \\
\hline 3 (3ß-3-Hydroxyolean-12-en-28-oate) & $<25.0 \mu \mathrm{M}$ \\
\hline Standard (Rutin) & $26.0 \pm 1.1 \mu \mathrm{M}$ \\
\hline
\end{tabular}

The values are expressed as mean \pm SEM while compound 3 inhibited $100 \%$ of the glycation formation in all examined concentrations $(200-25 \mu \mathrm{M})$

$\mathrm{EC}_{50}=$ The effective concentration that inhibited $50 \%$ glycation.

Table 3. Cytotoxicity of compounds $\mathbf{2}$ and $\mathbf{3}$ on normal lung cell line (WI-38).

\begin{tabular}{|c|c|c|}
\hline Compound & $\mathrm{CC}_{50}(\mu \mathrm{M})$ & MNTC $(\mu \mathrm{M})$ \\
\hline 2 (Lup-20(29)-en-3ß-ol) & $N$ & $>50.0$ \\
\hline 3 (3ß-3-Hydroxyolean-12-en-28-oate) & $57.44 \pm 2.0$ & 25.0 \\
\hline Cisplatin $(\mu \mathrm{g} / \mathrm{ml})$ & $2.26 \pm 0.035$ & 0.31 \\
\hline
\end{tabular}

MNTC $=$ Maximum nontoxic concentration; $N=$ The indicated compound did not show any cytotoxicity at the screening concentration $(50 \mu \mathrm{M})$, so no further test was carried out.

$\mathrm{CC}_{50}=$ Concentration caused $50 \%$ cytotoxicity to the normal WI-38 cell line. The tested compounds were firstly, screened at $50 \mu \mathrm{M}$, while only, the cytotoxic compound was subjected to further examination to determine their defined $\mathrm{CC}_{50}$. The values were determined by 48 hours SRB assay. Data given are derived from at least two independent experiments, expressed as mean \pm SEM. 
Table 4. Antiproliferative properties of compounds $\mathbf{2}$ and $\mathbf{3}$ isolated from Adonis microcarpa DC above-ground parts.

\begin{tabular}{|c|c|c|c|c|c|c|}
\hline \multirow{2}{*}{ Compound } & \multicolumn{6}{|c|}{ Cell proliferation $\mathrm{GI}_{50}(\mu \mathrm{M}) *($ mean $\pm \mathrm{SEM})$} \\
\hline & HepG2 & Huh-7 & MCF-7 & MB-MDA-231 & Caco-2 & HCT-116 \\
\hline Compound 2 & $52.56 \pm 3.99$ & $65 \pm 4.12$ & $45 \pm 3.10$ & $75 \pm 10.11$ & $42 \pm 3.99$ & $60 \pm 5.34$ \\
\hline Compound 3 & $52.82 \pm 1.42$ & $61.01 \pm 5.01$ & $23.24 \pm 0.99$ & $59.56 \pm 1.56$ & $18.14 \pm 1.98$ & $20.68 \pm 4.26$ \\
\hline Colchicine & $0.16 \pm 0.022$ & $0.244 \pm 0.06$ & $0.12 \pm 0.006$ & $0.65 \pm 0.06$ & $0.02 \pm 0.001$ & - \\
\hline Adricin $(\mu \mathrm{g} / \mathrm{ml})$ & $1.00 \pm 0.097$ & $1.25 \pm 0.075$ & $0.85 \pm 0.114$ & $1.37 \pm 0.13$ & $0.21 \pm 0.014$ & $1.43 \pm 0.13$ \\
\hline
\end{tabular}

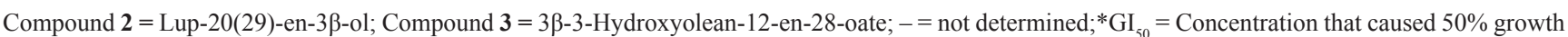
inhibition in the incubated cancer cells.

Values were determined by 48 hours SRB assay. Data given were derived from at least two independent experiments and expressed as mean \pm SEM.

Compound 2 could fight diabetes mellitus directly by inhibiting the enzymes (Nazaruk \& Borzym-Kluczyk, 2015) as indicated in the docking study in the present work and indirectly by suppressing the formed AGEs. Compound $\mathbf{2}$ introduced its antiproliferative activity against six examined cell lines at higher concentrations while $\mathrm{GI}_{50}>40 \mu \mathrm{M}$. Our data agreed with previous investigations in that lupeol has a higher therapeutic concentration margin and is reported as a nontoxic compound (Saleem, 2009). The antiproliferative properties of 3 $\beta$-3-hydroxyolean-12-en-28oate 3 against the same examined cancer cell lines were relatively ameliorated against three of the examined cancer cells compared to lup-20(29)-en-3 $\beta$-ol 2. It gave moderate activities with $\mathrm{GI}_{50}$ near $20 \mu \mathrm{M}$ (Table 4). The normal lung cells were subjected separately to the effect of compounds 2 (lup-20(29)-en-3 $\beta$-ol) and 3 (3ß-3-hydroxyolean-12-en-28-oate) to evaluate their exerted cytotoxicity on the normal cell line (WI-38). Compound $\mathbf{2}$ did not show any toxicity on the tested model of normal cells as shown in Table 3. 3 -3-hydroxyolean-12-en-28-oate 3 was toxic but at a considerable concentration $\left(\mathrm{CC}_{50}\right.$ was $\left.57.44 \mu \mathrm{M}\right)$.

In the current study, compound $\mathbf{3}$ was relatively nontoxic and has anticancer and antiglycation properties. Oleanolic acid was reported to promote insulin secretion from pancreatic $\beta$-cells (de Melo et al., 2010). A previous study reported this compound to exhibit lower $\mathrm{IC}_{50}$ values against the targeted enzymes of treating diabetes mellitus than the standard antidiabetic drug, acarbose (Choudhury et al., 2018). It has also been reported to improve blood glucose tolerance and ameliorates visceral obesity (de Melo et al., 2010). The compound was a potent inhibitor of $\alpha$-glucosidase rather than $\alpha$-amylase. The compound was suggested as possibly a better alternative to the antidiabetic drug acarbose and this is in line with our present data. Our study additionally showed that the molecular docking study of compound $\mathbf{3}$ using aldose reductase enzyme and redocking of the co-crystallized ligand was carried out to check its efficiency as hypoglycemic agents were confirmed (Figs. 3-5).

This compound has been reported as an active agent with antioxidant and anti-inflammatory activities. The relationship between the antioxidant and antiglycation properties was confirmed in many articles (Favre et al., 2020; Wölnerhanssen et al., 2020). In parallel with our finding, the compound has high inhibitory action of key enzymes linked to type 2 diabetes such as $\alpha$-amylase and $\alpha$-glucosidase (Choudhury et al., 2018; Mohammed et al., 2017). The phytochemical examination of the aqueous methanolic extract of the above-ground parts of $A$. microcarpa DC (Ranunculaceae) also led to the isolation of three strophanthidin glycosides: $\quad$ strophanthidin-3-O- $\beta$-D-glucopyranosyl-( $1 \rightarrow 4)-\beta$ -
D-digitoxoside 4 , strophanthidin-3- $O$ - $\beta$-glucopyranosyl-( $(1 \rightarrow 4)$ $\beta$-boiviopyranoside 5, and gluco- $(1 \rightarrow 6)$ strophanthidin $3-O-\beta$ glucopyranosyl-( $1 \rightarrow 4)-\beta$-boiviopyranoside 6 . The structures were assigned based on extensive 1D and 2D NMR experiments. Many strophanthidin as well as strophanthidin glucopyranosides have displayed selective cytotoxicity toward malignant tumor cell lines including HSC-2, HSC-3, HSC-4, and HL-60 cells with a $\mathrm{CC}_{50}$ range of $0.012-2.8 \mathrm{mM}$. Studies also indicated that they may trigger caspase-3-independent apoptotic cell death in HL-60 and HSC-2 cells. The $\mathrm{CC}_{50}$ values of the positive control melphalan were $8.7,25,32$, and $1.4 \mathrm{mM}$ in HSC-2, HSC-3, HSC-4, and HL-60 cells, respectively (Kubo et al., 2012). Amurensiosides A, $\mathrm{B}, \mathrm{D}$, and $\mathrm{E}$ were moderately cytotoxic to HSC-2 cells with $\mathrm{IC}_{50}$ values of $66,26,47$, and $58 \mathrm{mg} / \mathrm{ml}$, respectively; the activity of the positive control melphalan was $13 \mathrm{mg} / \mathrm{ml}$ (Kuroda et al., 2010). Many cardenolide glycosides have shown cytotoxic activities against HL-60 promyelocytic and HSC-2 cells (Kubo et al., 2015). Cymarilic acid, a compound isolated from the methanol extract of Adonis amurensis, has shown no significant cytotoxicity against tumor cell line A549 $\left(\mathrm{ED}_{50}>5 \mathrm{mg} / \mathrm{ml}\right)$ but was found to be strongly inhibitory toward tube formation induced by human umbilical vein endothelial cells (Shang et al., 2019). Cymarin and cymarol $(0.031$ and $0.021 \mathrm{mg} / \mathrm{ml})$ exhibited potent cytotoxicity against a human solid tumor cell line A549 (human lung carcinoma) while being inactive on murine leukemic cells (L1210, $5 \mathrm{mg} / \mathrm{ml}$ ) (Shang et al., 2019). The antiglycation properties of compounds $\mathbf{2}$ and $\mathbf{3}$ persuaded us to search for the possible biological target. Among a group of enzymes, $\alpha$-glucosidase and $\alpha$-amylase were selected as they are known to be inhibited by rutin (Dubey et al., 2017) which is the reference compound in the antiglycation assay (Table 2 ). The investigation of binding orientations of $\mathbf{2}$ and $\mathbf{3}$ that suffer from a shortage of hydrogen bond mediators was interesting to identify the impact of the hydrophobic interaction on stabilizing these compounds, which were proved biologically active.

\section{Molecular docking}

To produce dependable results, the validation of the process was planned by at least one of two theoretical techniques. The first one was applied for the three enzymes, and it was by redocking of the cocrystallized ligand which was carried out to check its efficiency as a hypoglycemic agent (Fig. 5).

The second theoretical technique was by docking rutin into $\alpha$-glucosidase (Fig. 3) and $\alpha$-amylase (Fig. 4). The redocking was approached by designing the native ligands from the $2 \mathrm{D}$ form and transformed them into the $3 \mathrm{D}$ structure which was followed 


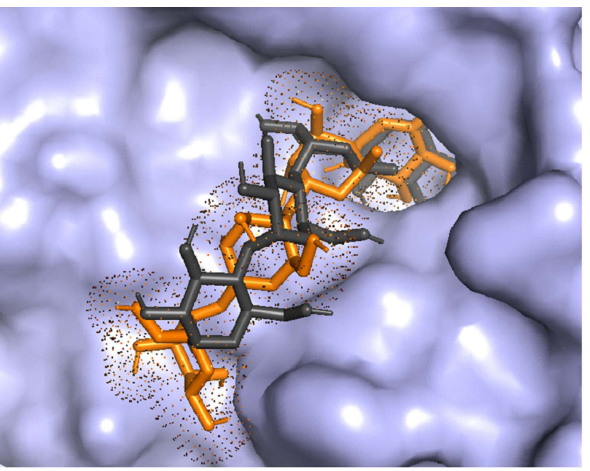

$\mathbf{a}$

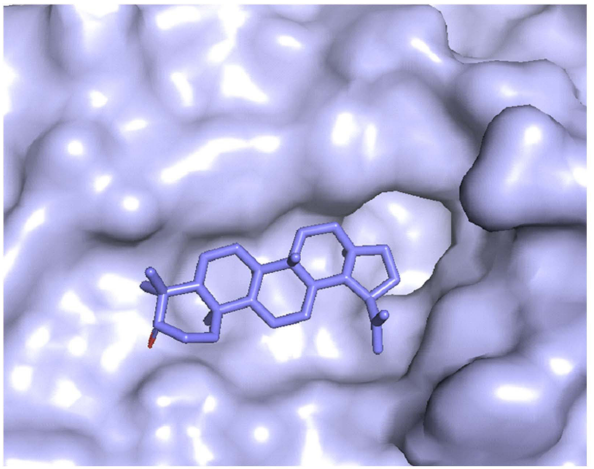

c

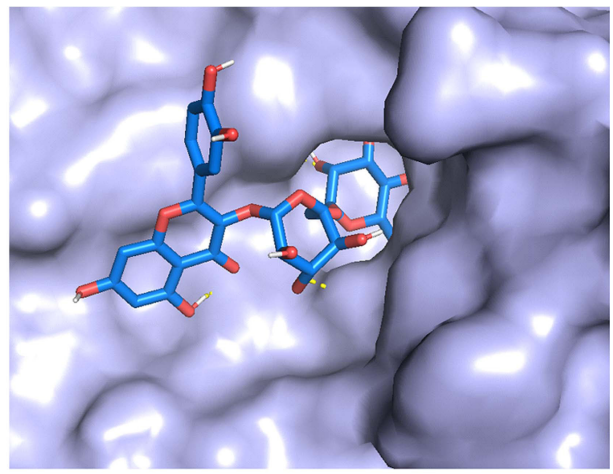

b

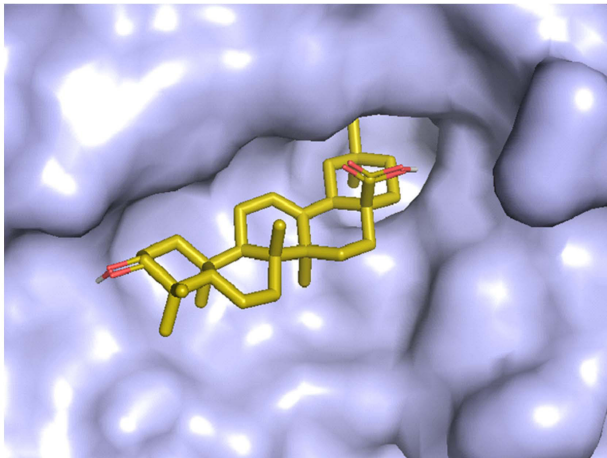

d

Figure 3. The docking trials toward $\alpha$-glucosidase: (a) native ligand (orange stick) in comparison to cocrystallized ligand (black stick), (b) rutin (blue stick), (c) compound $\mathbf{2}$ (light blue stick), and (d) compound $\mathbf{3}$ (yellow stick).

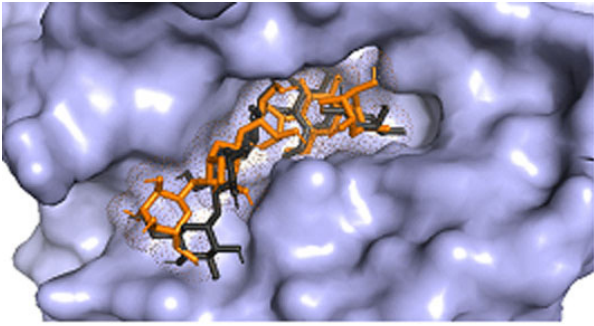

a

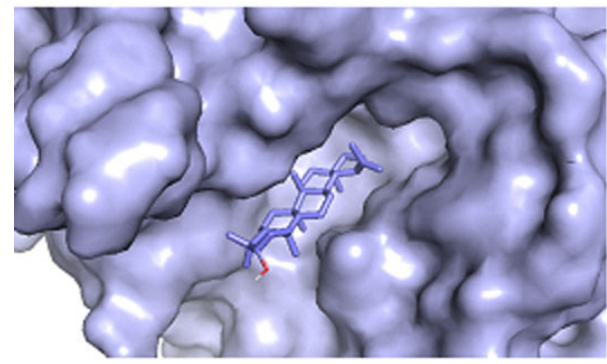

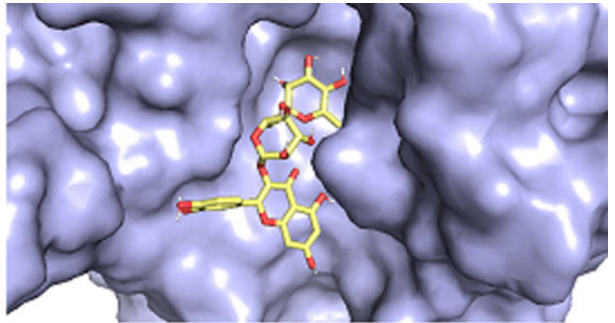

b

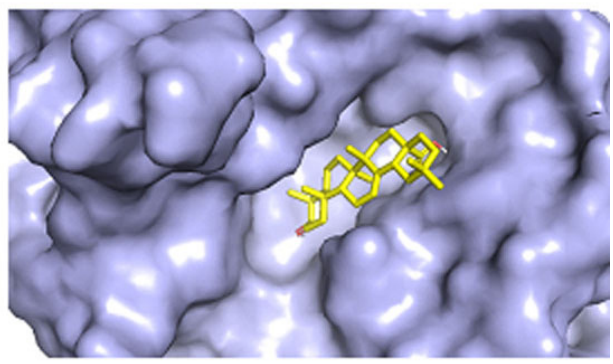

d

Figure 4. The molecular docking trial of $\alpha$-amylase: (a) native ligand (orange stick) in comparison to cocrystallized ligand (black stick), (b) rutin (blue stick), (c) compound 2 (light blue stick) and, (d) compound $\mathbf{3}$ (yellow stick). 


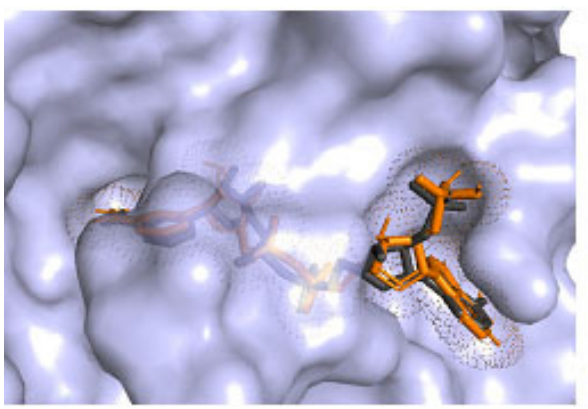

a

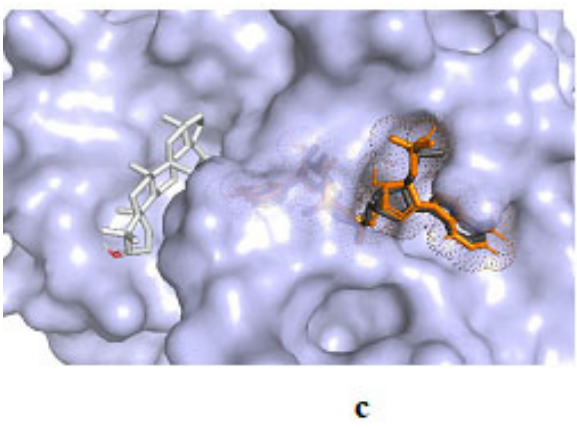

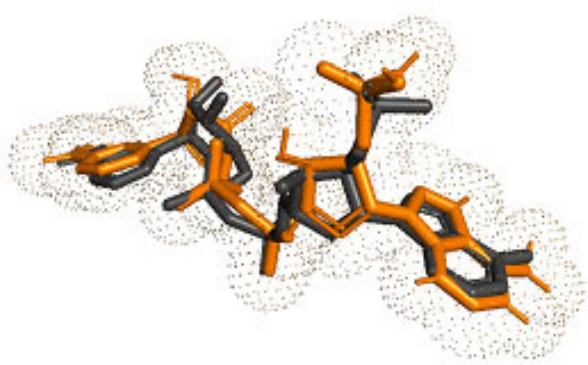

b

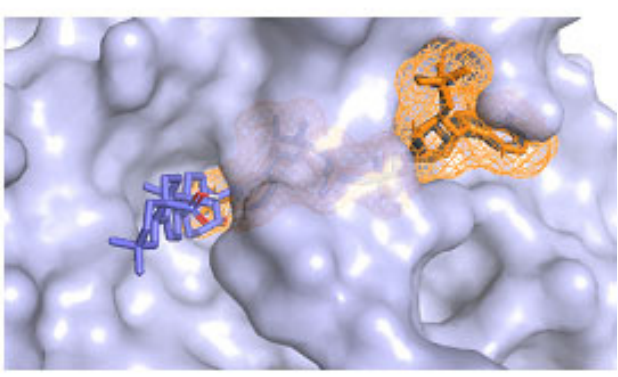

d

Figure 5. Crystal structure of molecular docking on aldose reductase: (a) superimposed binding modes of redocked and co-crystallized NADP inside the active pocket, (b) spatial orientation of the binding mode of theoretical and crystallized NADP, (c) the binding mode of compound $\mathbf{2}$ (white stick) inside the allosteric site, and (d) the binding mode of compound $\mathbf{3}$ in the allosteric site of the enzyme.

by energy minimization to pick up the best conformer. Designing the $3 \mathrm{D}$ structure of the native ligands and docking them rather than extraction and redocking of the ready-designed cocrystallized native ligand was preferable. It allowed us to validate the whole process, i.e., the energy minimization of the compounds, the docking algorithm, and the grid box parameters.

For $\alpha$-glucosidase, the redocking produced a binding mode of slight deviation from the cocrystallized one while it retained the same number of hydrogen bonds which was eight (Fig. 3). The theoretical affinity was not high $(-6.5 \mathrm{kcal} / \mathrm{mol})$ which was not expected. Rutin showed good affinity toward the enzyme that complies with the biological assay and the published data (Dubey et al., 2017). The affinity was $-8.7 \mathrm{kcal} / \mathrm{mol}$ and it formed five hydrogen bonds with the pocket (Fig. 3). The theoretical affinities of the compounds were moderate, -7.8 and $7.6 \mathrm{kcal} / \mathrm{mol}$ for $\mathbf{2}$ and $\mathbf{3}$, respectively. Compound $\mathbf{2}$ has only one hydrogen bond donor with no acceptor within the structure. The suggestion of being stabilized inside the enzyme by hydrophobic interaction towards the surrounding amino acids, Phe525, Trp481, and Asp282, was likely. Differently, 3 $\beta$-3-hydroxyolean-12-en28-oate 3 could form three hydrogen bonds as a maximum with the amino acid backbone. This position in which it formed the hydrogen bonds appeared less stable $(-7.3 \mathrm{kcal} / \mathrm{mol})$ which may make the hydrophobic interaction the significant contributor in stabilizing enzyme-compound $\mathbf{3}$ complex (Fig. 3). The allosteric binding possibility was tested by the blind docking approach and was found more probable for compound $\mathbf{3}$ than compound $\mathbf{2}$.

Compounds $\mathbf{2}$ and $\mathbf{3}$ showed higher stability inside $\alpha$-amylase which suggests this enzyme is responsible for their hypoglycemic activity. The redocked native ligand showed affinity toward the pocket of $-7.6 \mathrm{kcal} / \mathrm{mol}$ with fewer hydrogen bonds (eight) while it was twelve for the cocrystallized ligand (Fig. 4). The experimental efficacy of rutin was endorsed by docking, which showed an affinity of $-8.7 \mathrm{kcal} / \mathrm{mol}$ and formed five hydrogen bonds (Fig. 4). Compound 2 appeared to form a stable complex with the enzyme by probable hydrophobic interaction with Trp59, Trp62, and His305. These amino acids may also be involved in this stabilization of compound $\mathbf{3}$ which demonstrated an affinity of $-10.3 \mathrm{kcal} / \mathrm{mol}$ without forming any hydrogen bonds with the protein. The pose which developed three hydrogen bonds had a good affinity as well $(-8.5 \mathrm{kcal} / \mathrm{mol})$. Although the last affinity was inferior to the most stable pose, this binding mode represented a possibility (Fig. 4).

Aldose reductase is another possible target edited to the antiglycation activity of our compounds. The mechanism of inhibition of this enzyme is noncompetitive by binding the inhibitor with a binding site adjacent to the site of nicotinamide adenine dinucleotide phosphate (NADP) binding (Eisenmann et al., 2009; Rechlin et al., 2017; Zheng et al., 2012). The validation process showed excellent accuracy as the redocking of NADP inside the active site was typical to the crystallized ligand with high affinity $(-10.7 \mathrm{kcal} / \mathrm{mol})$ (Fig. 5). The grid box was adjusted to contain the active and allosteric sites. The docking trials of compounds $\mathbf{2}$ and 3 provided us with a good idea about their suggested inhibitory effect toward aldose reductase. The pentacyclic triterpenoid lup20(29)-en-3 $\beta$-ol 2 gave results that supported the published data (Ramu et al., 2014) and its binding poses were only limited to the allosteric site. The affinity of the picked pose was considerably high ( $-9 \mathrm{kcal} / \mathrm{mol})$; consequently, the ability of the enzyme to bind the substrate NADP may be impacted (Fig. 5). On the other 
Table 5. In silico ADMET predictions of the isolated compounds.

\begin{tabular}{|c|c|c|c|c|c|c|}
\hline & \multicolumn{6}{|c|}{ Compound number } \\
\hline & 1 & 2 & 3 & 4 & 5 & 6 \\
\hline \multicolumn{7}{|c|}{ Physicochemical properties } \\
\hline $\mathrm{MW}^{\mathrm{a}}$ & 152.15 & MW1 & 152.15 & MW1 & 152.15 & MW1 \\
\hline Rotatable bonds & 4 & 1 & 1 & 7 & 7 & 10 \\
\hline H-bond acceptors & 5 & 1 & 3 & 14 & 14 & 19 \\
\hline H-bond donors & 5 & 1 & 2 & 7 & 7 & 10 \\
\hline $\mathrm{MR}^{\mathrm{b}}$ & 31.96 & MR2 & 31.96 & MR2 & 31.96 & MR2 \\
\hline TPSA $^{\mathrm{c}}$ & 101.15 & TPSA3 & 101.15 & TPSA3 & 101.15 & TPSA3 \\
\hline Lipinski violations & 0 & 1 & 1 & 3 & 3 & 3 \\
\hline \multicolumn{7}{|c|}{ Lipophilicity and solubility } \\
\hline Consensus $\log \mathrm{P}^{\mathrm{d}}$ & -1.75 & 7.31 & 6.06 & -0.26 & -0.26 & -2.03 \\
\hline $\log \mathrm{S}\left(\right.$ ESOL class) ${ }^{\mathrm{e}}$ & Highly soluble & Poorly soluble & Poorly soluble & Soluble & Soluble & Soluble \\
\hline \multicolumn{7}{|l|}{ Absorption } \\
\hline GI absorption ${ }^{\mathrm{f}}$ & low & low & low & low & low & low \\
\hline $\begin{array}{l}\text { Human intestinal } \\
\text { absorption }\end{array}$ & + & + & + & + & + & + \\
\hline $\begin{array}{r}\text { Human oral } \\
\text { bioavailability }\end{array}$ & - & - & + & - & - & - \\
\hline Caco-2 permeability & - & - & + & - & - & - \\
\hline \multicolumn{7}{|l|}{ Distribution } \\
\hline $\begin{array}{l}\text { Plasma protein } \\
\text { binding }\end{array}$ & -0.14884 & 1.016751 & 1.036938 & 0.622995 & 0.622995 & 0.566022 \\
\hline $\begin{array}{l}\text { P-glycoprotein } \\
\text { substrate }\end{array}$ & - & - & - & + & + & + \\
\hline $\begin{array}{l}\text { Blood brain barrier } \\
\text { penetration }\end{array}$ & - & + & - & - & - & - \\
\hline \multicolumn{7}{|l|}{ Metabolism } \\
\hline \multicolumn{7}{|c|}{ a. Cytochrome P450: substrate and inhibitor } \\
\hline CYP1A2 inhibition & - & - & - & - & - & - \\
\hline CYP2C19 inhibition & - & - & - & - & - & - \\
\hline CYP2C9 inhibition & - & - & - & - & - & - \\
\hline CYP2C9 substrate & - & - & - & - & - & - \\
\hline CYP2D6 inhibition & - & - & - & - & - & - \\
\hline CYP2D6 substrate & - & - & - & - & - & - \\
\hline CYP3A4 inhibition & - & - & - & - & - & - \\
\hline CYP3A4 substrate & - & + & + & + & + & + \\
\hline $\begin{array}{l}\text { CYP inhibitory } \\
\text { promiscuity }\end{array}$ & - & - & - & - & - & - \\
\hline \multicolumn{7}{|c|}{ b. Pharmacokinetic transporters } \\
\hline $\mathrm{BRCP}$ inhibitor & - & - & - & - & - & - \\
\hline BSEP inhibitor & - & + & + & + & + & + \\
\hline OATP1B1 inhibitor & + & + & + & + & + & + \\
\hline OATP1B3 inhibitor & + & - & + & + & + & + \\
\hline OATP2B1 inhibitor & - & - & - & - & - & - \\
\hline OCT1 inhibitor & - & + & + & - & - & - \\
\hline \multicolumn{7}{|l|}{ Excretion } \\
\hline MATE1 inhibitor & - & - & - & - & - & - \\
\hline
\end{tabular}




\begin{tabular}{|c|c|c|c|c|c|c|}
\hline & \multicolumn{6}{|c|}{ Compound number } \\
\hline & 1 & 2 & 3 & 4 & 5 & 6 \\
\hline \multicolumn{7}{|l|}{ Toxicity } \\
\hline \multicolumn{7}{|l|}{ c. Organ toxicity } \\
\hline Hepatotoxicity & - & - & - & - & - & - \\
\hline $\begin{array}{l}\text { Human either-a-go-go } \\
\text { inhibition }\end{array}$ & - & - & - & + & + & + \\
\hline Acute oral toxicity (c) & IV & III & III & I & I & I \\
\hline Eye corrosion & - & - & - & - & - & - \\
\hline Eye irritation & - & - & - & - & - & - \\
\hline \multicolumn{7}{|l|}{ Genomic toxicity } \\
\hline Ames mutagenesis & - & - & - & - & - & - \\
\hline $\begin{array}{l}\text { Carcinogenicity } \\
\text { (binary) }\end{array}$ & - & - & - & - & - & - \\
\hline Micronuclear & - & - & - & - & - & - \\
\hline \multicolumn{7}{|l|}{ Other important ADMET } \\
\hline $\begin{array}{l}\text { Androgen receptor } \\
\text { binding }\end{array}$ & - & + & + & + & + & + \\
\hline Aromatase binding & - & + & + & + & + & + \\
\hline $\begin{array}{l}\text { Estrogen receptor } \\
\text { binding }\end{array}$ & - & + & + & + & + & + \\
\hline $\begin{array}{l}\text { Glucocorticoid } \\
\text { receptor binding }\end{array}$ & - & + & + & + & + & + \\
\hline $\begin{array}{l}\text { P-glycoprotein } \\
\text { inhibitor }\end{array}$ & - & - & - & + & + & + \\
\hline PPAR gamma & - & - & + & + & + & + \\
\hline $\begin{array}{l}\text { Subcellular } \\
\text { localization }\end{array}$ & Mitochondria & Lysosomes & Mitochondria & Mitochondria & Mitochondria & Mitochondria \\
\hline $\begin{array}{l}\text { Thyroid receptor } \\
\text { binding }\end{array}$ & - & + & + & - & - & - \\
\hline UGT catalyzed & + & + & - & + & + & + \\
\hline
\end{tabular}

${ }^{a}$ Molecular weight. MW1: 426.72 for compound 2, 712.82 for 4, and 874.96 for $\mathbf{6}$; MR2: 135.14 for 2, 175.52 for 4 and 207.91 for $\mathbf{6}$. MWa is 456.70 for compound $\mathbf{3}$ and 712.82 for $\mathbf{5}$.

${ }^{\mathrm{b}}$ Molar refractivity.

'Topological polar surface area. TPSA3: 20.23 for compound 2, 221.90 for 4, and 301.95 for $\mathbf{6}$.

${ }^{\mathrm{d}}$ Average of 5 method predictions (iLOGP, XLOGP, WLOGP3, MLOGP, and SILICO-IT).

${ }^{e}$ Water solubility class.

${ }_{\mathrm{f}}^{\mathrm{f}}$ Gastro -intestinal absorption.

hand, compound $\mathbf{3}$ showed a low affinity toward the enzyme $(-7.4$ $\mathrm{kcal} / \mathrm{mol})$. The binding mode in which the compound was inserted deeply in the inhibitory site of the enzyme and consequently the tremendous steric effect toward the bound substrate appeared less possible (affinity: $-5.5 \mathrm{kcal} / \mathrm{mol}$ ) (Fig. 5). However, the reported activity of compound $\mathbf{3}$ on aldose reductase was suggested to be suppressive during the transcription stage (Wang et al., 2010).

Adonitol or xylitol is a five-carbon polyol (Fig. 1) that is produced from d-xylose. Xylitol has been used since the early 1960 s in the diet of diabetic patients and, most recently, as a sweetener in products aimed at improved oral health (Wölnerhanssen et al., 2020). It is characterized by the same sweetness and bulk as sucrose with one-third fewer calories. It has no unpleasant aftertaste and insulin is not required for its metabolism (Deo et al., 2020). Considerable effort has been made to seek and identify inhibitors of the glycated proteins to alleviate the severity of diabetes complications (Deo et al., 2020; Favre et al., 2020; Wölnerhanssen et al., 2020). The present study explores the chemical composition of the aqueous methanolic extract of the above-ground parts of $A$. microcarpa DC (Ranunculaceae) and its total cardiac glycosides content. Also, it explores the potential of the two pentacyclic triterpenoids (compounds $\mathbf{2}$ and $\mathbf{3}$ ) as promising future antiglycation agents (Table 2).

According to the molecular modeling study, a slight superiority of compound $\mathbf{3}$ was recorded. Aldose reductase (Fig. 5) could be inhibited by the triterpenoid 2 in a noncompetitive manner while the triterpenoid $\mathbf{3}$ was probably inactive toward it. Also, this study has investigated the antiproliferative potential on six human cancer cell lines in addition to a normal human lung fibroblast (WI-38) and both compounds were not cytotoxic on the examined normal cell line. 


\section{In silico ADMET parameters}

In silico physicochemical properties, ADMET parameters, of the isolated compounds are predicted and summarized in Table 5. The promised compounds 1, 2, and $\mathbf{3}$ were found to be favorable in an acceptable prediction.

Our study showed the importance of $A$. microcarpa and hence investigation of sustainable usage practices is necessary for this species. In China, the above-ground parts of another Adonis species, Adonis vernalis, are harvested from the wild as a raw material for the pharmaceutical industry (Shang et al., 2019). With the abundant use of this species as well as slow plant growth, this resource has rapidly decreased and is close to extinction (Lange, 2000). Since 1982, A. vernalis has been protected in several countries and its trade was banned in many East European countries.

\section{CONCLUSION}

The present study provides insight into A. microcarpa above-ground parts and lays a solid foundation for further development of this plant. Furthermore, it can be concluded that $A$. microcarpa above-ground parts are a rich pool of pentacyclic triterpenoids ( $\mathbf{2}$ and $\mathbf{3}$ ). They are potent natural sources that possess the potential to be developed into a natural supplement to aid the management process of hyperglycemia-associated type 2 diabetes and as inhibitors of the glycated proteins. Additionally, compound 3 rather than 2 could be considered a potent antiproliferative agent against the tested colon cancer cell lines. Also, the in silico approach has predicted the toxicity of $A$. microcarpa. Further clinical evaluation of activity should be conducted after addressing the problem of the rapidly decreasing resources.

\section{ACKNOWLEDGMENTS}

The authors thank the partial financial support of the National Research Centre (NRC).

\section{AUTHOR CONTRIBUTIONS}

All authors made substantial contributions to conception and design, acquisition of data, or analysis and interpretation of data; took part in drafting the article or revising it critically for important intellectual content; agreed to submit to the current journal; gave final approval of the version to be published; and agree to be accountable for all aspects of the work. All the authors are eligible to be authors as per the International Committee of Medical Journal Editors (ICMJE) requirements/guidelines.

\section{ETHICAL APPROVALS}

This study does not involve experimentation on animal or human subjects.

\section{CONFLICT OF INTEREST}

The authors report no financial or any other conflicts of interest in this work.

\section{PUBLISHER'S NOTE}

This journal remains neutral with regard to jurisdictional claims in published institutional affiliation.

\section{REFERENCES}

Abd-Alla HI, Albalawy MA, Aly HF, Shalaby NM, Shaker KH. Flavone composition and antihypercholesterolemic and antihyperglycemic activities of Chrysanthemum coronarium 1. Z Naturforsch C J Biosci, 2014; 69:199-208.

Abd-Alla HI, Shalaby NM, Hamed MA, El-Rigal NS, AlGhamdi SN, Bouajila J. Phytochemical composition, protective and therapeutic effect on gastric ulcer and alpha-amylase inhibitory activity of Achillea biebersteinii afan. Arch Pharm Res, 2016; 39:10-20.

Abd -Alla HI, Soltan MM, Hassan A, Taie HAA, Abo-Salem HM, Karam EA, El-Safty MM, Hanna AG. Cardenolides and pentacyclic triterpenes isolated from Acokanthera oblongifolia leaves: their biological activities with molecular docking study. Z Naturforsch C J Biosci, 2021; $76 \mathrm{c}(7-8)$

Ahmed HH, Hegazi MM, Abd-Alla HI, Eskander EF, Ellithey MS. Antitumour and antioxidant activity of some Red Sea seaweeds in Ehrlich ascites carcinoma in vivo. Z Naturforsch C J Biosci, 2011; 66:367-76.

Aly HF, Abd-Alla HI, Ali SA, Aba-Alez RT, Abu-Krisha MO, Mamdouh MM. Bioinformatics: inflammatory cytokines and attenuation of diabetes hypercholesterolemia-induced renal injury using morning glory and necklace pod extracts. Asian J Pharm Clin Res, 2017; 10:347-55.

Aly HF, Abd-Alla HI, Ali SA, Mamdooh MM, Aba-Alez RT, Abu-Krisha MT. Statistical data analysis which results from the biodiagnosis and bio-treatment of injured rats with the hyperlipidemia and hyperglycemia diseases. Asian J Pharm Clin Res, 2016; 9:122-30.

Cheng F, Li W, Zhou Y, Shen J, Wu Z, Liu G, Lee PW, Tang Y. Admetsar: a comprehensive source and free tool for assessment of chemical admet properties. J Chem Inf Model, 2012; 52:3099-105.

Choudhury H, Pandey M, Hua CK, Mun CS, Jing JK, Kong L, Ern LY, Ashraf NA, Kit SW, Yee TS, Pichika MR, Gorain B, Kesharwani P. An update on natural compounds in the remedy of diabetes mellitus: a systematic review. J Tradit Complement Med, 2018; 8:361-76.

Daina A, Michielin O, Zoete V. Swissadme: a free web tool to evaluate pharmacokinetics, drug-likeness and medicinal chemistry friendliness of small molecules. Sci Rep, 2017; 7:42717.

de Melo CL, Queiroz MG, Fonseca SG, Bizerra AM, Lemos TL, Melo TS, Santos FA, Rao VS. Oleanolic acid, a natural triterpenoid improves blood glucose tolerance in normal mice and ameliorates visceral obesity in mice fed a high-fat diet. Chem Biol Interact, 2010; 185:59-65.

Deo P, Chern C, Peake B, Tan SY. Non-nutritive sweeteners are in concomitant with the formation of endogenous and exogenous advanced glycation end-products. Int J Food Sci Nutr, 2020; 71:706-14.

Dubey S, Ganeshpurkar A, Ganeshpurkar A, Bansal D, Dubey N. Glycolytic enzyme inhibitory and antiglycation potential of rutin. Future J Pharm Sci, 2017; 3:158-62.

Eisenmann M, Steuber H, Zentgraf M, Altenkamper M, Ortmann R, Perruchon J, Klebe G, Schlitzer M. Structure-based optimization of aldose reductase inhibitors originating from virtual screening. ChemMedChem, 2009; 4:809-19.

Evdokimov PK. Composition of Adonis leiosepala. Khim Prir Soedin, 1979; 5:736.

Favre LC, Rolandelli G, Mshicileli N, Vhangani LN, Dos Santos Ferreira C, van Wyk J, Buera MDP. Antioxidant and anti-glycation potential of green pepper (Piper nigrum): optimization of beta-cyclodextrin-based extraction by response surface methodology. Food Chem, 2020; 316:126280.

Franco RR, da Silva Carvalho D, de Moura FBR, Justino AB, Silva HCG, Peixoto LG, Espindola FS. Antioxidant and anti-glycation capacities of some medicinal plants and their potential inhibitory against digestive enzymes related to type 2 diabetes mellitus. J Ethnopharmacol, $2017 ; 215: 140-6$

Galal AMF, Soltan MM, Ahmed ER, Hanna AG. Synthesis and biological evaluation of novel 5-chloro-n-(4-sulfamoylbenzyl) salicylamide derivatives as tubulin polymerization inhibitors. Med Chem Comm, 2018; 9:1511-28. 
Hosseini M, Taherkhani M, Ghorbani Nohooji M. Introduction of Adonis aestivalis as a new source of effective cytotoxic cardiac glycoside. Nat Prod Res, 2019; 33:915-20.

Islam MT, Freitas RM, Sultana I, Hossain JA, Mahmood A, Kundu AK. Revision: chemical and biological activities of Corchorus olitorious. J Am Pharm Tech Res, 2013; 3:337-48.

Justino AB, Miranda NC, Franco RR, Martins MM, Silva NMD, Espindola FS. Annona muricata Linn. leaf as a source of antioxidant compounds with in vitro antidiabetic and inhibitory potential against alphaamylase, alpha-glucosidase, lipase, non-enzymatic glycation and lipid peroxidation. Biomed Pharmacother, 2018; 100:83-92.

Kubo S, Kuroda M, Matsuo Y, Masatani D, Sakagami H, Mimaki Y. New cardenolides from the seeds of Adonis aestivalis. Chem Pharm Bull, 2012; 60:1275-82.

Kubo S, Kuroda M, Yokosuka A, Sakagami H, Mimaki Y. Amurensiosides 1-p, five new cardenolide glycosides from the roots of Adonis amurensis. Nat Prod Commun, 2015; 10:27-32.

Kuroda M, Kubo S, Uchida S, Sakagami H, Mimaki Y. Amurensiosides a-k, 11 new pregnane glycosides from the roots of Adonis amurensis. Steroids, 2010; 75:83-94.

Lange D. Conservation and sustainable use of Adonis vernalis, a medicinal plant in international trade. Federal Agency for Nature Conservation, Münster, Germany, 2000.

Lei ZH, Yahara S, Nohara T, Shan TB, Xiong JZ. Cardenolides from Erysimum cheiranthoides. Phytochemistry, 1996; 41:1187-9.

Leow MK. Glycated hemoglobin (HbA1c): clinical applications of a mathematical concept. Acta Inform Med, 2016; 24:233-8.

Mahato SB, Kundu AP. 13c nmr spectra of pentacyclic triterpenoids-a compilation and some salient features. Phytochemistry, 1994; 37:1517-75

Matsuura N, Aradate T, Sasaki C, Kojima H, Ohara M, Hasegawa J, Ubukata M. Screening system for the maillard reaction inhibitor from natural product extracts. J Health Sci, 2002; 48:520-26.

Maurus R, Begum A, Williams LK, Fredriksen JR, Zhang R, Withers SG, Brayer GD. Alternative catalytic anions differentially modulate human alpha-amylase activity and specificity. Biochemistry, 2008; 47:3332-44.

Menezes-de-Oliveira D, Aguilar MI, King-Diaz B, VieiraFilho SA, Pains-Duarte L, Silva GD, Lotina-Hennsen B. The triterpenes 3beta-lup-20(29)-en-3-ol and 3beta-lup-20(29)-en-3-yl acetate and the carbohydrate 1,2,3,4,5,6-hexa-o-acetyl-dulcitol as photosynthesis light reactions inhibitors. Molecules, 2011; 16:9939-56.

Mohammed A, Gbonjubola VA, Koorbanally NA, Islam MS. Inhibition of key enzymes linked to type 2 diabetes by compounds isolated from Aframomum melegueta fruit. Pharm Biol, 2017; 55:1010-6.

Nazaruk J, Borzym-Kluczyk M. The role of triterpenes in the management of diabetes mellitus and its complications. Phytochem Rev, $2015 ; 14: 675-90$.

Oboh G, Isaac AT, Akinyemi AJ, Ajani RA. Inhibition of key enzymes linked to type 2 diabetes and sodium nitroprusside induced lipid peroxidation in rats' pancreas by phenolic extracts of avocado pear leaves and fruit. Int J Biomed Sci, 2014; 10:208-16.

Pedretti A, Villa L, Vistoli G. Atom-type description language: a universal language to recognize atom types implemented in the vega program. Theor Chem Acc, 2003; 109:229-32.

Ramu R, Shirahatti PS, Zameer F, Ranganatha LV, Prasad MN. Inhibitory effect of banana (Musa sp. Var. Nanjangud rasa bale) flower extract and its constituents umbelliferone and lupeol on $\alpha$-glucosidase, aldose reductase and glycation at multiple stages. South Afr J Bot, 2014; 95:54-63.

Rechlin C, Scheer F, Terwesten F, Wulsdorf T, Pol E, Fridh V, Toth P, Diederich WE, Heine A, Klebe G. Price for opening the transient specificity pocket in human aldose reductase upon ligand binding: structural, thermodynamic, kinetic, and computational analysis. ACS Chem Biol, 2017; 12:1397-415.
Roig-Zamboni V, Cobucci-Ponzano B, Iacono R, Ferrara MC, Germany S, Bourne Y, Parenti G, Moracci M, Sulzenbacher G. Structure of human lysosomal acid $\alpha$-glucosidase-a guide for the treatment of pompe disease. Nat Commun, 2017; 8:1111.

Saleem M. Lupeol, a novel anti-inflammatory and anti-cancer dietary triterpene. Cancer Lett, 2009; 285:109-15.

Schrodinger. The axpymol molecular graphics plugin for microsoft powerpoint, Version 1.8. Nature Publishing Group, Schrödinger, LLC, New York, 2015.

Shaaban M, Hassan AZ, Soltan MM, Abdelwahab AB. Naturally bioactive compounds from Hemimycale aff arabica: antimicrobial, antiglycation, cytotoxicity, and molecular docking studies. Med Chem Res, 2018; 27:2079-88.

Shalaby NMM, Abd-Alla HI, Aly HF, Albalawy MA, Shaker $\mathrm{KH}$, Bouajila J. Preliminary in vitro and in vivo evaluation of antidiabetic activity of Ducrosia anethifolia boiss. and its linear furanocoumarins. Biomed Res Int, 2014; 2014:480545.

Shang X, Miao X, Yang F, Wang C, Li B, Wang W, Pan H, Guo X, Zhang Y, Zhang J. The genus Adonis as an important cardiac folk medicine: a review of the ethnobotany, phytochemistry and pharmacology. Front Pharmacol, 2019; 10:25.

Solich P, Sedliaková V, Karlíček R. Spectrophotometric determination of cardiac glycosides by flow-injection analysis. Anal Chim Acta, 1992; 269:199-203.

Thieme H, Lamzhav A. Ueber die cardenolidglycoside von Adonis mongolica sim. Pharmazie, 1976; 25:1976.

Trott O, Olson AJ. Autodock vina: Improving the speed and accuracy of docking with a new scoring function, efficient optimization, and multithreading. J Comput Chem, 2010; 31:455-61.

Vichai V, Kirtikara K. Sulforhodamine B colorimetric assay for cytotoxicity screening. Nat Protoc, 2006; 1:1112-6.

Wang ZH, Hsu CC, Huang CN, Yin MC. Anti-glycative effects of oleanolic acid and ursolic acid in kidney of diabetic mice. Eur J Pharmacol, 2010; 628:255-60.

Wölnerhanssen BK, Meyer-Gerspach AC, Beglinger C, Islam MS. Metabolic effects of the natural sweeteners xylitol and erythritol: a comprehensive review. Crit Rev Food Sci Nutr, 2020; 60:1986-98.

Yoshikawa M, Murakami T, Shimada H, Fukada N, Matsuda H, Sashida Y, Yamahara J. Corchorusosides a, b, c, d, and e, new cardiotonic oligoglycosides from the seeds of Corchorus olitorius 1. (moroheiya). Heterocycles, 1998; 48:869-73.

Zhang BW, Xing Y, Wen C, Yu XX, Sun WL, Xiu ZL, Dong YS. Pentacyclic triterpenes as $\alpha$-glucosidase and $\alpha$-amylase inhibitors: structure-activity relationships and the synergism with acarbose. Bioorg Med Chem Lett, 2017; 27:5065-70.

Zhang HD, Zhang SJ, Chen YZ. Studies on chemical constituents of Adonis coerulea maxim-a tibetan medicinal herb. J Lanzhou Univ, 1991; 27:88-92.

Zheng X, Zhang L, Zhai J, Chen Y, Luo H, Hu X. The molecular basis for inhibition of Sulindac and its metabolites towards human aldose reductase. FEBS Lett, 2012; 586:55-9.

How to cite this article:

Abd-Alla HI, Hassan AZ, Soltan MM, Abdelwahab AB, Hanna AG. Potential protein antiglycation, antiproliferation, and in silico study on the antidiabetic enzymes of bioactive metabolites from Adonis microcarpa DC and their ADMET properties. J Appl Pharm Sci, 2022; 12(01):106-119. 